\title{
Continuous-flow Size Selection of Tetrahymena pyriformis ST: Changes in Volume, DNA, RNA and Protein during Synchronous Growth
}

\author{
By CAROL A. PHILLIPS* AND DAVID LLOYD \\ Department of Microbiology, University College, Newport Road, Cardiff CF2 1TA
}

(Received 14 September 1977; revised 10 November 1977)

\begin{abstract}
The cell cycle of Tetrahymena pyriformis ST was studied using synchronous cultures prepared by continuous-flow size selection. These organisms had cell cycle times (mean values 151 and $186 \mathrm{~min}$ in the first and second cycles respectively) similar to but not identical with the mean generation times of exponential cultures from which they were selected (mean value $165 \mathrm{~min}$ ). The median volume of cells averaged over the duration of the cell cycle in synchronous cultures was similar to that found in exponential cultures. Total cell DNA, RNA and protein doubled during the cell cycle: there was one discrete $S$ phase which occupied 40 to $50 \%$ of the cell cycle time during the period between the end of the selection procedure and the first synchronous division. Total cell protein and RNA increased continuously.
\end{abstract}

\section{INTRODUCTION}

Tetrahymena pyriformis was the first eukaryotic organism to be synchronized in bulk cultures by the much used heat-shock method (Scherbaum \& Zeuthen, 1954). Since then a number of other synchronizing procedures have been applied to this organism including pressure changes (Zimmerman \& Laurence, 1975), starvation (Stone \& Prescott, 1964; Cameron \& Jeter, 1970; Rudick \& Cameron, 1972), colchemid treatment (Wunderlich \& Peyk, 1969) and exposure to vinblastine (Stone, 1968; Sedgely \& Stone, 1969). However, all these induction procedures lead to the production of synchronous cultures having distorted cell cycles. The only successful approach to selection synchrony of $T$. pyriformis has been the method of Hildebrandt \& Duspiva (1969) which takes advantage of the fact that dividing organisms do not form food vacuoles and so do not ingest iron filings or tantalum particles: the phagocytic portion of the population can then be removed with a magnet or by density gradient centrifugation (Wolfe, 1973; Dickinson, Graves \& Swoboda, 1976). Cultures which have been synchronized in this way show one period of DNA synthesis per cell cycle in contrast to the varied patterns of synthesis found in cultures synchronized by earlier induction procedures, although the recently devised heat-shock method of Zeuthen (1974) also gives synchronous cultures in which DNA replication and cell division are closely coupled.

In this investigation a new selection synchrony procedure, continuous-flow size selection (Lloyd et al., 1975), has been used to study the general characteristics of synchronous growth in cultures which have been exposed to minimal perturbating influences $(<440 \mathrm{~g}$ for $<20 \mathrm{~s}$ at unchanged concentrations of $\mathrm{O}_{2}$ and all nutrients, and at the optimum growth temperature).

* Present address: Department of Radiopharmacology, Institute of Cancer Research, Royal Cancer Hospital, Sutton, Surrey SM2 5PX. 


\section{METHODS}

Maintenance and growth of the organism. Tetrahymena pyriformis strain ST (amicronucleate) was obtained from Dr Y. Suyama (Department of Biology, University of Pennsylvania, Philadelphia, U.S.A.). The cultures were maintained and grown as described previously by Turner, Lloyd \& Chance (1971).

Preparation of synchronous cultures. Synchronous cultures were prepared and cell numbers estimated as described by Lloyd et al. (1975). The actual values for the inlet flow rate and rotor speed used to obtain about $10 \%$ of the original population in the effluent from the continuous-flow centrifuge are given in the figure legends.

Assessment of synchrony. The degree of synchrony was assessed by the synchrony index of Blumenthal \& Zahler (1962) calculated from the equation:

$$
F=\left(N / N_{0}\right)-2^{t / g}
$$

in which $F$ has a maximum value of 1.0 in a culture exhibiting theoretical perfect synchrony, $N$ is the number of organisms at time $t, N_{0}$ is the number of organisms at zero time and $g$ is the mean generation time. In the presentation of results, vertical lines indicate the mid-points in doublings of cell numbers and $F_{1}$ and $F_{2}$ the synchrony indices of the first and second doublings in cell numbers respectively.

Measurement of cell volume. This was determined using a Coulter counter model $\mathbf{Z}_{\mathbf{B}}$ connected to a model P-64 size distribution analyser and an X-Y recorder II (Coulter Electronics, Dunstable, Bedfordshire), and fitted with a $140 \mu \mathrm{m}$ orifice tube. Preliminary experiments indicated that $T$. pyriformis changed in volume when solutions of $\mathrm{NaCl}$ were used as diluent, therefore all volume frequency distributions were carried out with cells still in their growth medium. The instrument was calibrated with spherical polystyrene latex beads $(21.04 \pm 1.06 \mu \mathrm{m}$ diameter, measured directly with a split-image eyepiece), suspended in fresh sterile growth medium with 'gain' set at 5 and matching resistance set at $20 \mathrm{k} \Omega$.

Measurement of total cell protein, DNA and RNA. Total cell protein was measured in organisms from $10 \mathrm{~m}$ samples of culture by the method of Herbert, Phipps \& Strange (1971), using bovine serum albumin as

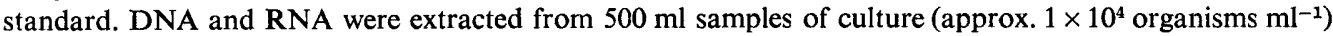
by the method of Herbert et al. (1971). The extracts thus prepared contained $98 \%$ of the DNA in the sample and all the RNA. Total DNA was estimated by the method of Burton (1956) as improved by Giles \& Myers (1965), using calf thymus DNA as standard. Total RNA in the extract was determined by the orcinol method of Herbert et al. (1971), using yeast RNA as standard.

Measurement of DNA content by flow cytofluorimetry. Samples $(20 \mathrm{ml})$ of culture (approx. $1 \times 10^{4}$ organisms $\mathrm{ml}^{-1}$ ) were fixed, incubated with RNAase and stained with propidium iodide according to the procedure of Krishan (1975). The stained cells were analysed in a cytofluorograph (model $4802 \mathrm{~A}$; Bio/Physics System, Matopal, New York, U.S.A.) connected to a multi-channel pulse height distribution analyser (model 2100; Bio/Physics System) which displays, as a histogram, the frequency distribution of the pulses as a function of the magnitude of the fluorescence signal. Excitation (by a focused argon ion laser beam at $488 \mathrm{~nm}$ ) of individual stained cells was produced as they passed through the optical flow channel. The abscissa of the histogram reflects increasing values of the fluorescence signal and hence increasing DNA content of individual organisms.

\section{RESULTS}

Tetrahymena pyriformis ST has a biphasic pattern of exponential growth on proteose peptone/liver extract medium (Lloyd et al., 1971), the mean generation time during the rapid growth phase being $165 \pm 20$ min (11 experiments). Synchronous cultures could be prepared by continuous-flow size selection from both phases of exponential growth (Fig. 1). Satisfactory synchrony indices were obtained in both cases but in all experiments subsequently described cultures of the type shown in Fig. $1(b)$ were used. The cell cycle times differed slightly from the mean generation times calculated for the corresponding phase of exponential growth: for the type of culture shown in Fig. 1(b) the times were $151 \pm 18$ min (35 experiments) for the first cell cycle and $186 \pm 18 \mathrm{~min}$ for the second cycle ( 35 experiments). The cell cycle time in the first cycle was measured from time zero to the time of completion of the first cell division whilst that for the second cycle was taken as the interval between the mid-points of the first and second divisions. 


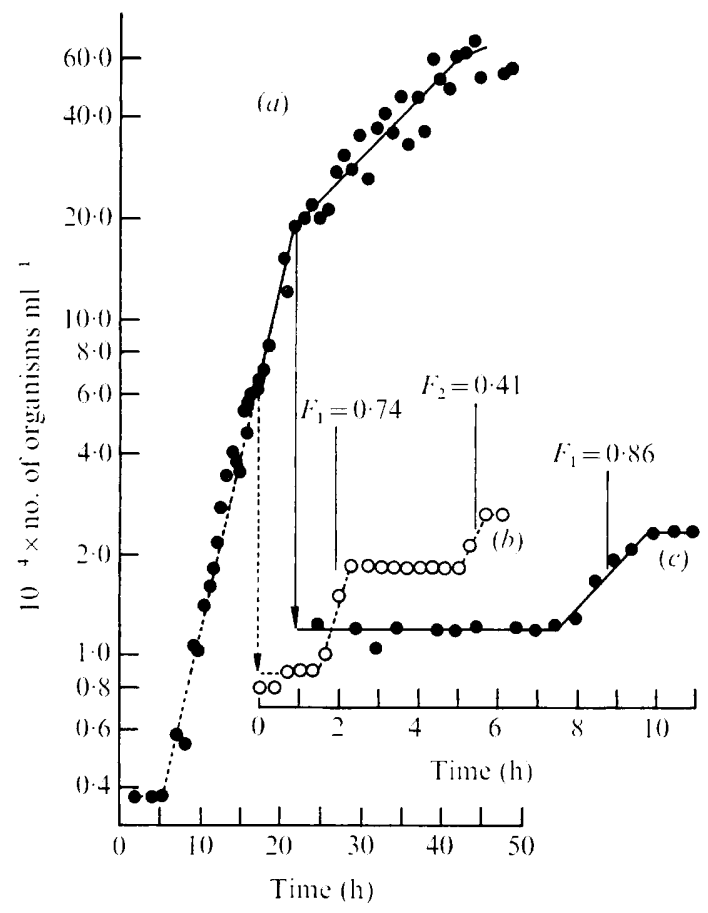

Fig. 1. Cell numbers in ( $a$ ) an exponentially growing culture of $T$. pyriformis and $(b, c)$ synchronous cultures prepared by continuous-flow size selection. The synchronous culture in $(b)$ was obtained by passing the exponentially growing culture through the rotor $\left(2800 \mathrm{rev} . \mathrm{min}^{-1}\right)$ at $1.151 \mathrm{~min}^{-1}$ when the population of organisms had reached $6.6 \times 10^{4} \mathrm{ml}^{-1}$; under these conditions $12 \%$ of the original population remained in the rotor effluent. The corresponding conditions for culture $(c)$ were $2600 \mathrm{rev} . \mathrm{min}^{-1}$ at $1.151 \mathrm{~min}^{-1}$ when the population had reached $1.8 \times 10^{5}$ organisms $\mathrm{ml}^{-1}$ ( $7 \%$ of the griginal population selected). The ordinate refers to all three growth curves.

\section{Changes in cell volume during synchronous growth}

Changes in the distribution of cell volumes in the synchronous population are shown in Fig. 2, and the corresponding changes in median cell volumes are presented in Fig. 3. A continuous increase in the median volume of the population occurred throughout each cell cycle; this increase was $60 \%$ in the first cell cycle after size selection (Fig. 3) but was only $27 \%$ during the second cell cycle, probably as a consequence of the decay of synchrony. (Corresponding values for mean cell volume increases were $58 \%$ and $21 \%$ respectively.) Analysis of 15 separate synchronous cultures showed that only $73 \pm 6 \%$ of the total population underwent the second division and it seems probable that only these cells increase in volume during the second cell cycle. At least two factors contribute to the incomplete doubling in cell volume: (i) the natural variation in cell size at cell division, i.e. the size distribution of $10 \%$ of the exponentially growing population which constitutes the starting population of the synchronous culture; and (ii) the imperfect synchrony, especially consideration of the observation that many cells fail to divide in the second cycle.

\section{Changes in total nucleic acids as determined by chemical estimation}

Figure 4 shows the changes in DNA and RNA content of synchronously growing cultures; the synchrony indices were satisfactory. The DNA content per ml culture doubled from the mid-point of the first division to the mid-point of the second division. The average weight of DNA per cell ( $15 \mathrm{pg}$ ) was similar to that determined for an exponential culture $(16.5 \mathrm{pg})$. The $\mathrm{S}$ phase of the cell cycle lasted approximately $60 \mathrm{~min}$ and occupied 45 to 


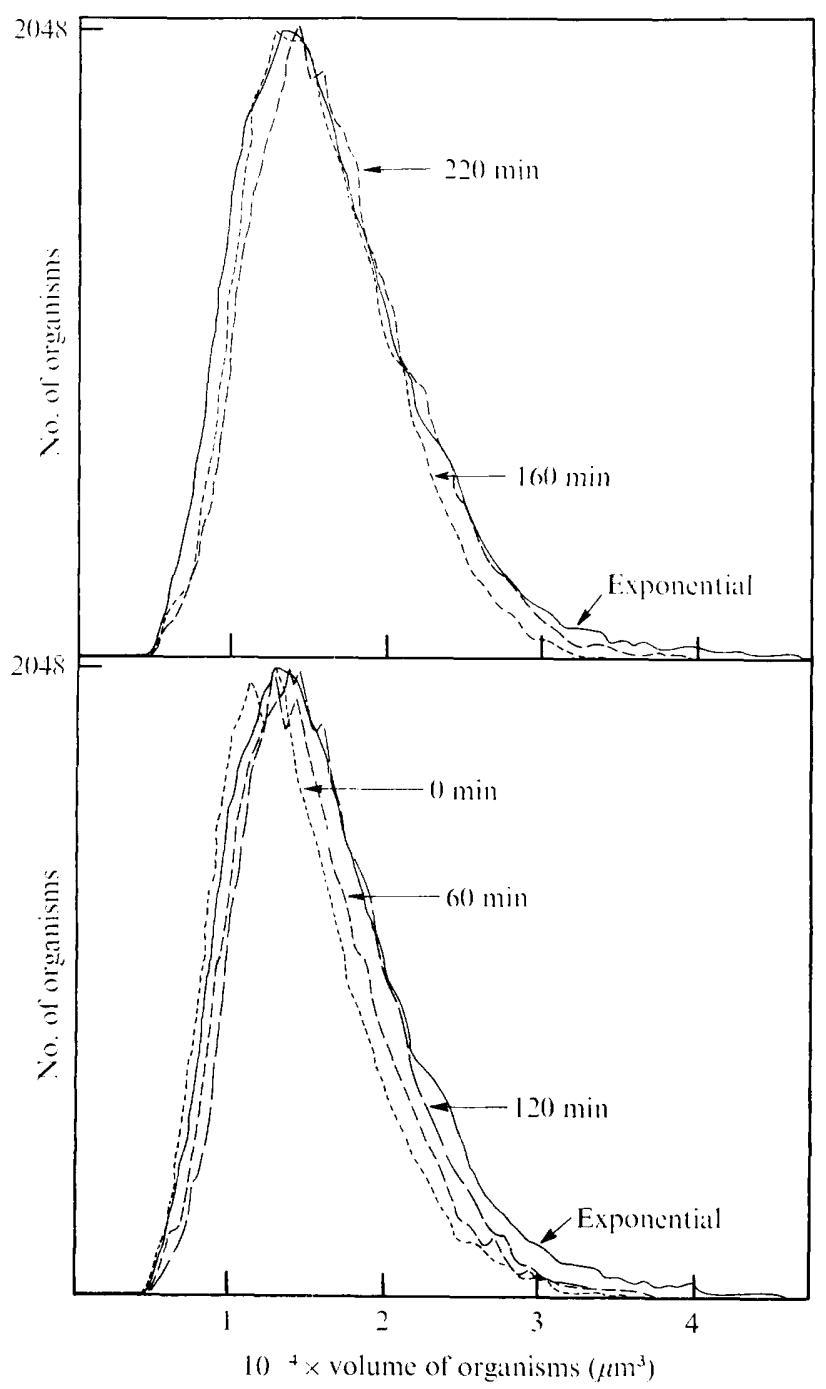

Fig. 2. Changes in size distribution of cell populations of $T$. pyriformis during growth of a synchronous culture. The synchronous culture was obtained by passing an exponentially growing culture $\left(6.6 \times 10^{4}\right.$ organisms $\left.\mathrm{ml}^{-1}\right)$ through the continuous-flow rotor $\left(2800 \mathrm{rev} . \mathrm{min}^{-1}\right)$ at $1.151 \mathrm{~min}^{-1}$; $12 \%$ of the original population was selected. The increase in cell numbers in this culture is shown in Fig. 3. Size distributions of cell populations were determined in a Coulter counter model $Z_{B}$ fitted with a P-64 Channelyser (64 channels). Settings were as follows: $I \times A, 32$; lower threshold, 6 ; upper threshold, off; matching resistance, $20 \mathrm{k} \Omega$; gain, 5 ; edit switch, on. The orifice diameter was $140 \mu \mathrm{m}$. Channels with most organisms contained 2048 counts. Times refer to the growth curve shown in Fig. 3.

$50 \%$ of the total cell cycle time. The $\mathrm{G}_{1}$ phase occupied $40 \%$ and the $\mathrm{G}_{2}$ phase 10 to $15 \%$ of the total cell cycle time, respectively.

The RNA content of the culture increased continuously and doubled between successive divisions. However, it was difficult to determine the type of increase (i.e. whether it was exponential, or linear with a rate increase at a particular point in the cell cycle) and many more points need to be analysed to determine the difference between these two patterns of synthesis. The calculated average weight of RNA per cell $(0.3 \mathrm{ng})$ was similar to that determined for an exponential culture $(0.45 \mathrm{ng})$. 


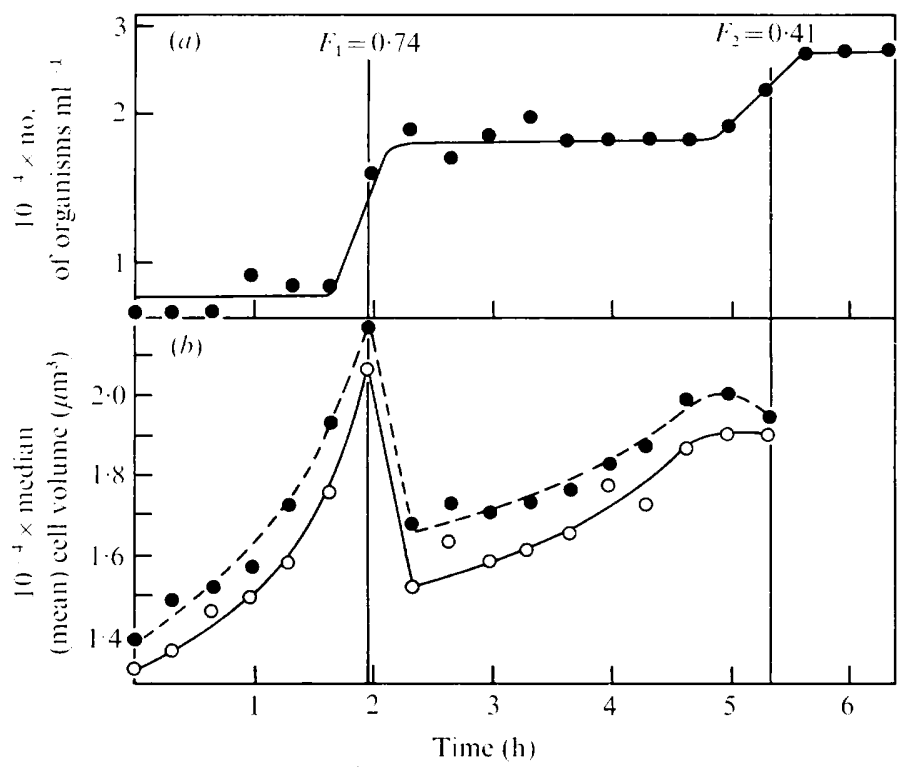

Fig. 3. Changes in median cell volumes of populations of $T$. pyriformis in a synchronous culture. The conditions for continuous-flow size selection and determinations of size distributions are given in the legend to Fig. 2. (a) Growth; (b) median cell volumes (O), mean cell volumes (O).

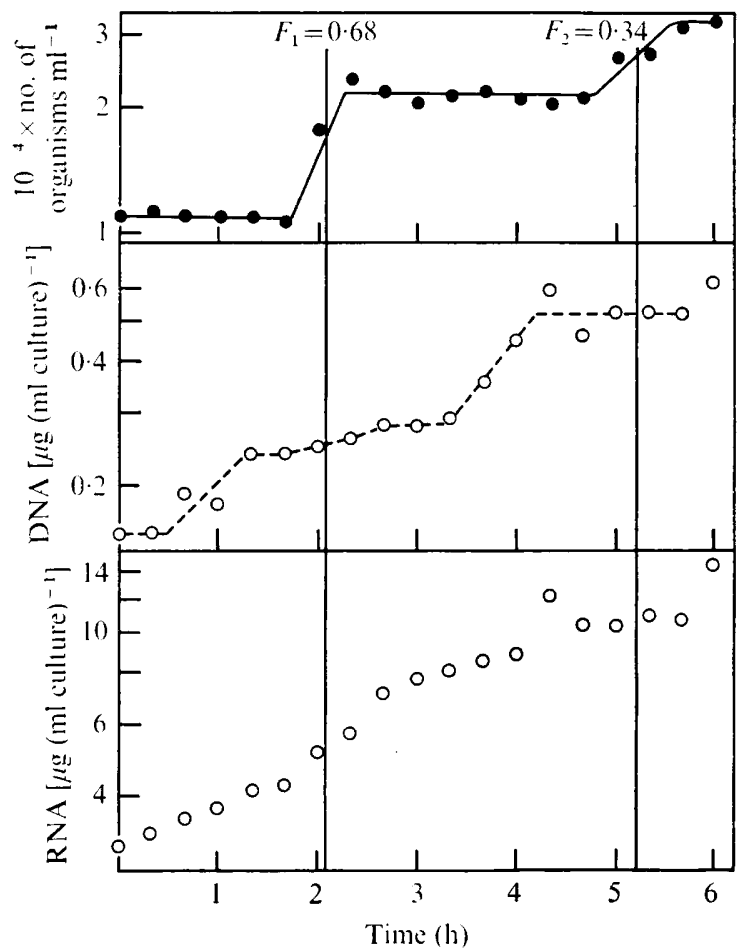

Fig. 4. Changes in DNA and RNA content of a synchronous culture of T. pyriformis. The synchronous culture was obtained by passing an exponentially growing culture $\left(1 \cdot 1 \times 10^{5}\right.$ organisms $\left.\mathrm{ml}^{-1}\right)$ through the continuous-flow rotor $\left(2700 \mathrm{rev} . \mathrm{min}^{-1}\right)$ at $1.151 \mathrm{~min}^{-1} ; 10 \%$ of the original population was selected. 


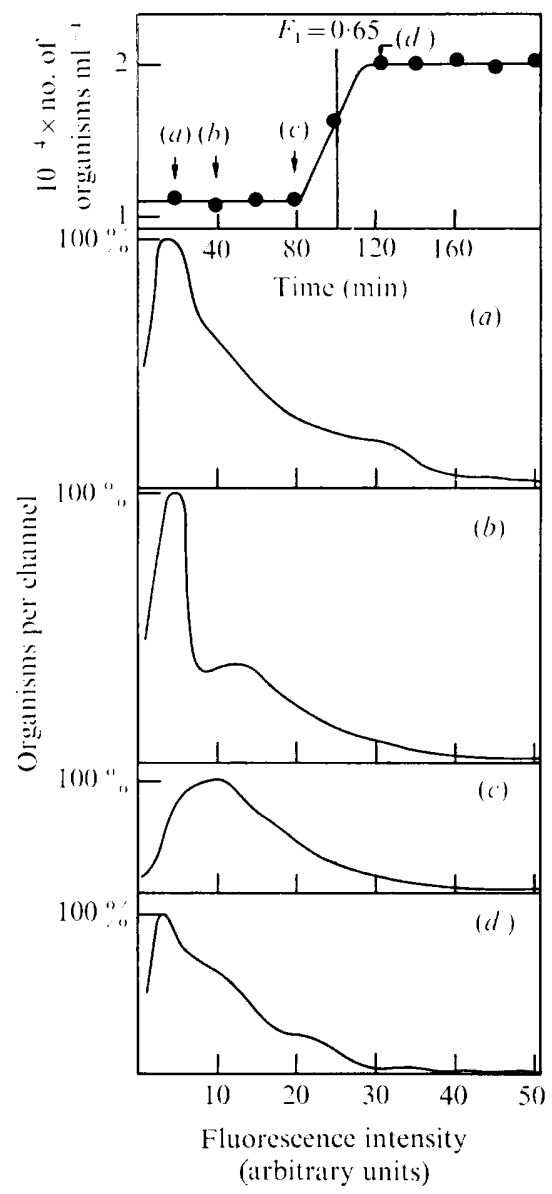

Fig. 5. Frequency distribution histograms of cell DNA content of $T$. pyriformis determined by flow cytofluorimetry. $(a),(b),(c)$ and $(d)$ are frequency distributions of fluorescence emission of propidium iodide-DNA complex in populations of organisms taken at the times indicated on the growth curve. Percentage selection from the exponentially growing culture used for the preparation of the synchronous.culture by continuous-flow size selection was $13.5 \%$

\section{DNA content determined by flow cytofluorimetry}

Distributions of DNA (Fig. 5) were obtained by analysing cells, after fixing and staining, in a flow cytofluorimeter. [Distributions $(a),(b)$ and $(d)$ gave maximum fluorescence in channels 7 and 8 of the instrument.] Since fluorescence is proportional to the DNA content per cell, the cell population shown in distribution $(c)$ has twice as much DNA per cell as those cells in $(a)$ or $(d)$, and is in the $\mathrm{G}_{2}$ phase of the cell cycle. Distribution of DNA in $(b)$ was bimodal, some of the organisms were in the $S$ phase, others in the $G_{2}$ phase. Thus the $S$ phase took place between 40 and $80 \mathrm{~min}$ and occupied $40 \%$ of the cell cycle; the $G_{1}$ phase occupied $40 \%$, and the $\mathrm{G}_{2}$ phase $20 \%$ of the total cell cycle time, respectively.

\section{Synthesis of total protein}

Total cell protein increased continuously during the cell cycle (Fig. 6). Despite the scatter in the points an exponential curve could be drawn although more frequent points would be needed to distinguish between this pattern of increase and a linear one with a rate increase at a particular point in the cell cycle. The amount of total cell protein approximately doubled during the cell cycle, thus fulfilling one of the criteria for 'balanced growth'. 


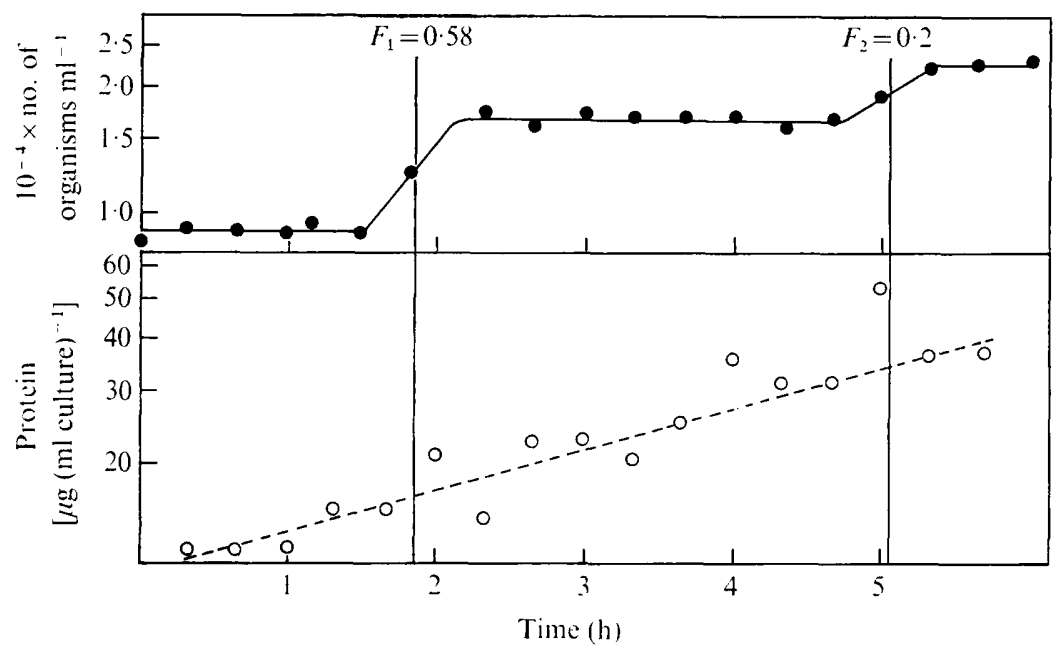

Fig. 6. Changes in protein content of a synchronous culture of $T$. pyriformis. The synchronous culture was obtained by passing an exponentially growing culture $\left(9.4 \times 10^{4}\right.$ organisms $\left.\mathrm{ml}^{-1}\right)$ through the continuous-flow rotor $\left(2800 \mathrm{rev} . \mathrm{min}^{-1}\right)$ at $1.151 \mathrm{~min}^{-1} ; 10 \%$ of the original population was selected.

\section{DISCUSSION}

In heat-shock synchronized $T$. pyriformis (Jeffrey, 1969), macronuclear DNA synthesis continues while the division cycle is arrested and new $\mathrm{S}$ phases or periods are periodically initiated (Hjelm \& Zeuthen, 1967). During the temperature-shock procedure many cells complete two $\mathrm{S}$ phases during the first interdivision period which lasts about twice the normal generation time. In both temperature-shocked and pressure-treated $T$. pyriformis there was no observable $\mathrm{G}_{1}$ phase; an increase in $\left[{ }^{14} \mathrm{C}\right]$ thymidine incorporation was observed as early as $10 \mathrm{~min}$ after the completion of the synchronization procedure with the $\mathrm{S}$ phase taking up to $80 \%$ of the total cycle time (Zimmerman \& Laurence, 1975). In T. pyriformis synchronized by starvation and refeeding, $25 \%$ of the refed cells divide without synthesizing DNA (Rudick \& Cameron, 1972) and the first cell cycle time is abnormally long. However, the new heat-shock procedure of Zeuthen (1974), in which a single temperature perturbation is applied to each cell cycle, gives much more 'normal' cell growth, especially with respect to synchrony of DNA replication which is tightly coupled to the growth cycle.

The selection method of synchrony used in this study produced no such distortions to the timing or extent of DNA synthesis but did lead to somewhat altered generation times. The cells synthesized DNA once during each synchronous cell cycle time, and the generation times were similar to but not identical with those of an exponential culture. In $T$. pyriformis strain GL-C synchronized by selection synchrony (Wolfe, 1973), the synthesis of DNA was similar to that observed here. In a cell cycle time of $170 \mathrm{~min}$, the $S$ phase occupied 60 to $90 \mathrm{~min}$, the $G_{1}$ phase $30 \mathrm{~min}$ and the $G_{2}$ phase $50 \mathrm{~min}$, also corresponding to timings reported by Cameron \& Nachtwey (1967) for exponential cultures of the same strain. The length of the $\mathrm{S}$ phase of strain ST synchronized by continuous-flow size selection is similar to that found in other strains synchronized by other selection techniques, but the $G_{1}$ and $\mathrm{G}_{2}$ phases are different in respect to each other. This may be due either to an inherent property of the strain or to the growth conditions (Cameron \& Nachtwey, 1967; Cleffman, 1967). Attempts to check the duration of the $S$ phase in strain sT by pulsed incorporation of [methyl $\left.-^{3} \mathrm{H}\right]$ thymidine have been unsuccessful as strain ST is capable of extensive degradation of this compound to precursors which are incorporated into many cellular components other than DNA (J. F. Hogg, personal communication).

RNA synthesis occurs continuously through the cell cycle with no gap during nuclear 
division (Prescott, 1964). In heat-shock synchronized T. pyriformis, the synthesis of all major classes of RNA occurs during the period between the end of the synchronizing heat treatment and the first synchronous division (Yuyama \& Zimmerman, 1972). Total RNA in this case shows a continuous increase, although the individual RNAs show different patterns of synthesis. In pressure-induced division synchrony there is a $50 \%$ increase in $\left[{ }^{3} \mathrm{H}\right]$ uridine incorporation between 20 and $40 \mathrm{~min}$ after the end of the synchronizing procedure (Zimmerman \& Laurence, 1975). In the present study the total RNA doubled during the cell cycle (Fig. 4) and this observation fulfils one of the criteria of 'balanced growth'.

The amount of total cell protein also doubled during the cell cycle, as has been shown in other organisms synchronized by gradient centrifugation, e.g. Schizosaccharomyces pombe (Mitchison \& Wilbur, 1962) and Crithidia fasciculata (Edwards, Stathan \& Lloyd, 1975). The rate of protein synthesis is continuous throughout the cell cycle; it does not show the slight decrease at cell division found in cells synchronized by induction procedures (Kuzmich \& Zimmerman, 1972; Zimmerman \& Laurence, 1975).

After multicycle heat-shock treatment, organisms are abnormal in size (Scherbaum \& Zeuthen, 1954). This is not the case with organisms used in this study as is shown by comparison of the median cell volumes of the synchronous culture $\left(1 \cdot 3 \times 10^{4}\right.$ to $\left.2 \cdot 3 \times 10^{4} \mu \mathrm{m}^{3}\right)$ and the median value for the exponential culture from which the synchronous culture was selected $\left(1.5 \times 10^{4} \mu \mathrm{m}^{3}\right)$. The Coulter counter used for the determination of cell volume has an advantage over direct microscopic measurement in that in the direct measurement procedure no account is taken of asymmetry even if the cell is assumed to be a prolate sphere in the calculations (Ricketts \& Rappitt, 1974). Figure 2 confirms that the continuousflow procedure does select a small size class from the exponentially growing population; the slightly short first cell cycle time may indicate that the selected population is not the smallest size class (Poole, 1977). The percentage increase in cell volume observed during the first cell division cycle is similar to that found during cell cycle fractionation (Lloyd et al., 1977).

The experiments with cultures of $T$. pyriformis synchronized by various induction procedures have yielded valuable insights into the mechanism of cell division, but cannot give information on the natural undisturbed cell cycle. The advantage of the continuous flow method is that organisms suffer no temperature shocks, osmotic changes, nutrient deprivation or anoxia as they never leave their growth medium. No obvious metabolic disturbances (e.g. abnormally elevated or depressed $Q_{\mathrm{O}_{2}}$ values or levels of adenylates) have been observed in synchronous populations of $T$. pyriformis obtained by this procedure, despite the incomplete synchrony in the second cell division. Thus the method provides an opportunity to study the natural cell cycle of the archetypal organism for cell synchrony studies.

We are indebted to Shandon Southern Ltd for the use of flow cytofluorometric equipment and to Mr E. W. Meyer for his expert help. C.A.P. held a University College postgraduate studentship.

\section{REFERENCES}

Blumenthal, L. K. \& Zahler S. A. (1962). Index for measurement of synchronization of cell populations. Science, 135, 724.

Burton, K. (1956). A study of the conditions and mechanism of the diphenylamine reaction for the colorimetric estimation of deoxyribonucleic acid. Biochemical Journal 62, 315-322.

Cameron, I. L. \& JeTer, J. R. (1970). Synchronization of the cell cycle of Tetrahymena by starvation and refeeding. Journalof Protozoology 17, 429-431.

Cameron, I. L. \& Nachtwey, D. S. (1967). DNA synthesis in relation to cell division in Tetrahymena pyriformis. Experimental Cell Research 46, 385395.

Cleffman, G. (1967). Temperaturabhängigkeit der Phasen der Teilungszyklen von Tetrahymena pyriformis HSM. Zeitschrift für Zellforschung und mikroskopische Anatomie 79, 599-602.

Dickinson, J. R., Graves, M. G. \& Swoboda, B. E. P. (1976). Cyclic AMP metabolism in the cell cycle of Tetrahymena pyriformis. FEBS Letters 65, 152-154. 
Edwards, C., Statham, M. \& Lloyd, D. (1975). The preparation of large-scale synchronous cultures of the trypanosomatid, Crithidia fasciculata, by cell-size selection: changes in respiration and adenylate charge through the cell-cycle. Journal of General Microbiology 88, 141-152.

Giles, K. W. \& Myers, A. (1965). An improved diphenylamine method for the estimation of deoxyribonucleic acid. Nature, London 206, 93.

Herbert, D., Phipps, P. J. \& Strange, R. E. (1971). Chemical analysis of microbial cells. Methods in Microbiology 5B, 209-344.

HildebrandT, A. \& Duspiva, F. (1969). Eine einfache Methode zur Synchronisation grösserer Populationen des Ciliaten Tetrahymena pyriformis. Zeitschrift für Naturforschung 24B, 747-750.

Huelm, K. K. \& Zeuthen, E. (1967). Synchronous DNA synthesis induced by synchronous cell division in Tetrahymena. Experimental Cell Research 48, 231-233.

JEFFREY, W. R. (1969). The effect of synchronizing heat shocks on macro-nuclear DNA synthesis in Tetrahymena pyriformis strain GL-C. Journal of Cell Biology 43, 59a.

KrISHAN, A. (1975). Rapid flow cytofluorimetric analysis of mammalian cell cycle by propidium iodide staining. Journal of Cell Biology 66, 188193.

KuZmich, M. J. \& ZimmermanN, A. M. (1972). Colchemid action on the division schedule of synchronized Tetrahymena. Experimental Cell Research 72, 441-452.

Lloyd, D., Brightwell, R., Venables, S. E., ROACH, G. I. \& TURNER, G. (1971). Subcellular fractionation of Tetrahymena pyriformis ST by zonal centrifugation: changes in activities and distribution of enzymes during the growth cycle and on starvation. Journal of General Microbiology 65, 209-223.

Lloyd, D., John, L., Edwards, C. \& Chagla, A. H. (1975). Synchronous cultures of micro-organisms: large-scale preparation by continuous-flow size selection. Journal of General Microbiology 88, 153-158.

Lloyd, D., John, L., Hamill, M., Phillips, C., KADER, J. \& EdWARds, S. W. (1977). Continuousflow cell cycle fractionation of eukaryotic microorganisms. Journal of General Microbiology 99, 223-227.

Mitchison, J. M. \& Wilbur, K. M. (1962). The incorporation of protein and carbohydrate precursors during the cell cycle of fission yeast. Experimental Cell Research 26, 144-157.

Poole, R. K. (1977). Continuous flow selection synchrony: which organisms are selected? FEMS Microbiology Letters 1, 305-307.

PrescotT, D. M. (1964). The normal cycle. In Synchrony in Cell Division and Growth, p. 71. Edited by E. Zeuthen. New York: Interscience.

Ricketts, T. R. \& RappitT, A. F. (1974). Determination of the volume and surface area of Tetrahymena pyriformis and their relationship to endocytosis. Journal of Protozoology 21, 549-551.

RUdick, M. J. \& CAMERON, I. L. (1972). Regulation of DNA synthesis and cell division in starved and refed synchronized Tetrahymena. Experimental Cell Research 70, 411-416.

Scherbaum, O. \& ZeUthen, E. (1954). Induction of synchronous cell division in mass cultures of Tetrahymena pyriformis. Experimental Cell Research 6, 221-227.

Sedgely, N. N. \& Stone, G. E. (1969). DNA synthesis in vinblastine synchronized Tetrahymena pyriformis. Experimental Cell Research 56, 174 177.

Stone, G. E. (1968). Synchronized cell division in Tetrahymena pyriformis following inhibition with vineblastine. Journal of Cell Biology 39, 556-563.

Stone, G. E. \& Prescott, D. M. (1964). Cell division and DNA synthesis in Tetrahymena pyriformis following inhibition with vineblastine. Journal of Cell Biology 21, 275-281.

Turner, G., Lloyd, D. \& Chance, B. (1971). Electron transport in phosphorylating mitochondria from Tetrahymena pyriformis strain ST. Journal of General Microbiology 65, 359-374.

WolfE, J. (1973). Differential density labelling and gradient centrifugation of Tetrahymena. Experimental Cell Research 77, 232-238.

Wunderlich, F. \& PEYK, D. (1969). Antimitotic agents and macronuclear division of ciliates. II. Endogenous recovery from colchicine and colchemid, a new method of synchronization in Tetrahymena pyriformis GL. Experimental Cell Research 57, 142-144.

YuYAmA, S. \& Zimmerman, A. M. (1972). RNA synthesis in Tetrahymena. Temperature-pressure studies. Experimental Cell Research 71, 194-202.

ZEUTHEN, E. (1974). A cellular model for repetitive and free-running synchrony in Tetrahymena and Schizosaccharomyces. In Cell Cycle Controls, p. 1-30. Edited by G. M. Padilla, I. L. Cameron and A. M. Zimmerman. New York: Academic Press.

Zimmerman, A. M. \& Laurence, H. L. (1975). Induction of division synchrony in Tetrahymena pyriformis. Experimental Cell Research 90, 119136. 